Historic, Archive Document

Do not assume content reflects current scientific knowledge, policies, or practices. 



\title{
The Buyers' Guide
}

of

"DEPENDABLE NURSERY STOCK"

\author{
Direct from
}

Grower to Planter

\section{Jillhalerate

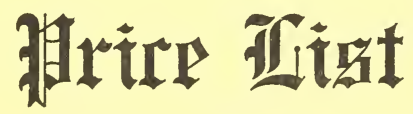

THOMAS MARKS \& CO.

Nurserymen and Fruit Growers

Wilson - - Niagara County - - New York 


\section{FRUIT DEPARTMENT}

Our fruit trees, Apple, Pear, Plum, Prune, Cherry and Peach are budded from selected fruiting orchards (in addition to our own) the owners being the most progressive and prominent fruit growers of Niagara County.

\section{APPLE TREES}

Varieties listed as per Catalog. Each First Class, large size, 2 year No. 1 Grade, 5 to $7 \mathrm{ft} ., 3 / 4$ up. . $60 \mathrm{c}$ First Class, medium size, 4 to $6 \mathrm{ft} ., 5 / 8-3 / 4$ up.......... $45 \mathrm{c}$ First Class, light grade, 2 year, 4 to $5 \mathrm{ft} ., 1 / 2-5 / 8$ up....... $25 \mathrm{c}$ Ten $\$ 5.50$ 4.00 100 CORTLAND, 2 year, 5 to $7 \mathrm{ft}$., $60 \mathrm{c}$ each.

2.50 $\$ 50.00$ 30.00 20.00

\section{PEAR TREES}

Varieties listed as per Catalog.

First Class, large size, 2 year No. 1 Grade, 5 to $7 \mathrm{ft} . \ldots . \ldots 60 \mathrm{c}$

50.00

SPECIAL: Bartlett, Clapps Favorite, Seckel,

First Class, light grade, 2 year, 4 to $5 \mathrm{ft} . . \ldots \ldots \ldots \ldots . \ldots 40$

30.00

\section{PLUM TREES}

Varieties listed as per Catalog.

First Class, large size, 2 year No. 1 Grade, 5 to $7 \mathrm{ft......} 50 \mathrm{c}$

SPECIAL FELLEMBURG PRUNE.

First Class, light grade, 2 year, $3 \frac{1 / 2}{2}$ to $5 \mathrm{ft} . \ldots \ldots \ldots . \ldots 40 \mathrm{c}$

\section{CHERRY TREES}

Sweet Varieties as per Catalog.

First Class, large size, 2 year No. 1 Grade, 5 to $7 \mathrm{ft........} \mathrm{75c}$ First Class, one year, No. 1 Grade, 4 to $6 \mathrm{ft} . \ldots \ldots \ldots \ldots \ldots$........

\section{CHERRY TREES}

Sour varieties as per Catalog.

First Class, large size, 2 year No. 1 Grade, 5 to $6 \mathrm{ft} . . . \ldots \ldots 60 \mathrm{c}$

\section{QUINCE TREES}

Variety. Orange. None better grown.

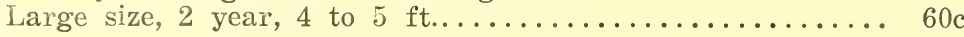

\section{PEACH TREES}

Our Speciality. The Standard of Excellence.

Varieties as per Catalog.

First Class, large size, No. 1 Grade, 4 to $6 \mathrm{ft} . \ldots \ldots \ldots . \ldots 40 \mathrm{c}$

First Class, light size, No. 1 Grade, 4 to $5 \mathrm{ft} . \ldots \ldots \ldots \ldots . \ldots 30 \mathrm{c}$

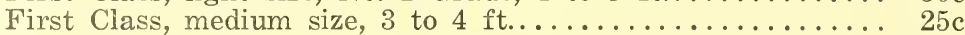

First Class, smaller size, Elberta, J. H. Hale, $2 \frac{1}{2}$ to $3 \frac{1 / 2}{\mathrm{ft} . .}$. 15c

\section{RED RASPBERRIES}

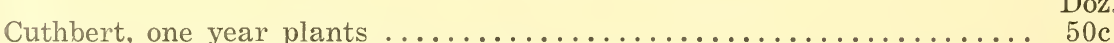




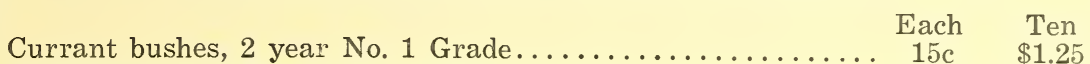

Gooseberries 2 ................ 15c $\$ 1.25$

Asparagus Washington, Rust proof. Special

2 year roots No. 1 grade. 25 for $\$ 1.00$. 100 for $\$ 2.50$. 1000 for $\$ 15.00$.

Rhubarb (Pieplant) Strong, 2 year roots............. 20c 1.50

\section{FLOWERING SHRUBS}

Prices of all varieties (except as noted)

Strong, thrifty bushes, 2 to $31 / 2 \mathrm{ft}$., 2 year............ $40 \mathrm{c}$

\section{SPECIAL BARGAINS}

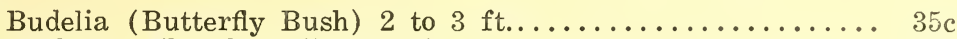

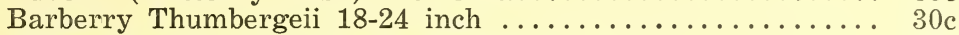

Hydrangea, P. G. 18 to 24 inch, strong, thrifty.......... 25c

2.25

Spirea Van Houteii 18 to 24 inch................. 25c

\section{GRAPE VINES}

Concord, one year No. 1 Grade................. 10c

Concord, 2 year No. 1 Grade....................... $15 \mathrm{c}$

All other Varieties as per Catalog, 2 year No. 1........ 20c

\section{HEDGING}

Barberry Thumbergeii, strong plants.............. 25c 2.00

\section{EVERGREENS}

American Arbor Vitae, 2 to $3 \mathrm{ft} .1 .00$ American Arbor Vitae, 3 to $4 \mathrm{ft}$. 1.50 Hemlock, 2 to $3 \mathrm{ft} . \ldots \ldots \ldots \ldots \ldots . . .1 .00$ Norway Spruce, 2 to $3 \mathrm{ft} . \ldots \ldots \ldots$.... 1.00

\section{EVERGREENS}

Norway Spruce, 3 to $4 \mathrm{ft} . . \ldots \ldots \$ 1.50$ Irish Juniper, 2 to $3 \mathrm{ft} . . . \ldots \ldots \ldots . . . .1 .50$ Colorado Blue Spruce, 2 to $3 \mathrm{ft} .$. . 5.00

\section{SHADE AND ORNAMENTAL TREES}

American Elm, 8 to $10 \mathrm{ft} . \ldots \ldots \ldots . . . \begin{aligned} & \text { Each } \\ & \$ 1.25\end{aligned}$

Ash Mountain, 6 to $8 \mathrm{ft} . . . \ldots \ldots . .1 .25$

Bechtels Fl'g Crab, 3 to $4 \mathrm{ft.....} 1.00$

Catalpa Bungeii, 2 yr. head 6/8. 2.00

Catalpa Speciosa, 8 to $10 \mathrm{ft} . . . . . \quad .75$

Cut-leaved Wp'g Birch, 5-6 ft... 2.50

IMaple Ash-leaved, 8-10 ft. ..... 1.00

Maple Silver-leaved, 8-10 ft...... 1.00

Maple Weirs Cut-leaved, $8-10 \mathrm{ft} . . .1 .50$

Mulberry Downing, 6-8 ft....... 1.00
Each

Mulberry Russian, 6-8 ft. ...... \$1.00

Mulberry Teas Wp'g, 5-6 ft. .... 2.00

Oriental Plane, $8-10 \mathrm{ft}$......... 1.00

Poplar Carolina, 8-10 ft......... .50

Poplar Lombardy, 8-10 ft...... .75

Thorn Dbl. Pink, 4-6 ft. ...... 1.50

Thorn Pauls Dbl. Scarlet, $4-6 \mathrm{ft} . . \quad 1.50$

Willow Babylonica, 5-6 ft...... 1.00

Willow Golden, 6-8 ft. ........ 1.00

ROSE BUSHES, strong, thrifty, 2 year old, bloomed in the nurseries the past season. All varieties as per Catalog. 50c each. $\$ 4.50$ per Ten. $50 \mathrm{c}$ each.

Climbing Vines, varieties as per Catalog (except as noted) 2 year No. 1, strong,

SPECIAL. Clematis Paniculata, 2 year No. $1.25 \mathrm{c}$ each.

Honeysuckle Halls Japan, 2 year No. 1. 25c each. list.

NOTE. -25 or over of one variety at 100 rates. This applies all through the price 


\section{TERMS. HOW TO REMIT}

Cash with order, except in large orders when satisfactory reference is given. We will ship trees and plants C.O.D. if $25 \%$ of the total amount of your order is sent in cash. The balance to be collected on delivery of stock.

Remittance should be made by check, postoffice money order, express money order or draft on New York bank, or registered letter.

\section{OUR RELIABILITY}

Your Banker will give you the desired information. Consult Dun's or Bradstreets Commercial Agencies, or write the Wilson State Bank, Wilson, N. Y. Our record for square dealing is open for investigation.

\section{DEPENDABLE NURSERY STOCK}

Our trees are grown in good soil, under ideal conditions, and are offered with the assurance that they are the Best obtainable and Guaranteed True to Name.

We depend on winning the future patronage of each customer on the firm basis of value received.

A trial order solicited.

No. 3256

\section{STATE OF NEW YORK \\ DEPARTMENT OF FARMS AND MARKETS}

BERNE A. PYRKE, Commissioner

\section{Certificate of Inspection of Nursery Stock}

This is to Certify that the nursery stock of Thomas Marks \& Co., of Wilson, County of Niagara, State of New York, was duly examined in compliance with the provisions of Article 14 of the Farms and Markets Law and was found to be apparently free from any contagious or infectious disease or diseases, or the San Jose scale, or other dangerously injurious insect pest or pests. This certificate expires September 1, 1927.

Dated, Albany, N. Y., September 1, 1926.

BERNE A. PYRKE, Commissioner.

By GEO. G. ATWOOD, Director Bureau of Plant Industry 